[Research Paper]

\author{
고층건축물 계단실 내 재실자의 합류를 고려한 \\ 수직보행속도 분석에 관한 연구 \\ 김윤성 · 이유림 ${ }^{*}$ 김혜원 ${ }^{* *}$ 권영진 $^{* * *}$ \\ 호서대학교 소방방재학과 석사과정, ${ }^{*}$ 동경이과대학 공학석사, ${ }^{* *}$ 호서대학교 소방방재학과 공학석사, \\ ***호서대학교 안전소방학부 교수
}

\title{
A Study on the Analysis of Vertical Walking Speed Considering the Confluence of Occupants in the Stainwell of a High-rise Building
}

\author{
Yun-Seong Kim $\cdot$ Yoo-Lim Lee ${ }^{*} \cdot$ Hye-Won Kim ${ }^{* *} \cdot$ Yeong-Jin Kwon ${ }^{* *+}$ \\ Graduate Student, Dept. of Fire Protection and Disaster Engineering, Hoseo Univ., \\ *Master of Engineering, Dept. of Global Fire Science and Technology, Tokyo Univ. of Science, \\ ${ }^{* *}$ Master of Engineering, Dept. of Fire Protection and Disaster Engineering, Hoseo Univ., \\ ${ }^{* * *}$ Professor, Division of Safety and fire Protection, Hoseo Univ.
}

(Received August 5, 2021; Revised August 19, 2021; Accepted August 27, 2021)

요 약

고층화, 복합화되는 현대 건축물에서 화재가 발생했을 때 대다수의 재실자는 계단실을 이용하여 피난하기 때문에 계단실과 같은 수직피난로의 안전성을 확보하는 것은 매우 중요한 요소이다. 하지만 국내에서는 계단실의 크기를 일괄적인 기준으로 규정하고 있으며, 건축물의 수직피난 시 발생할 수 있는 재실자의 행동특성에 관한 규정 및 연구 는 부족한 실정이다. 따라서 본 연구에서는 일본의 W대학에서 실제로 진행된 피난실험을 분석하여 계단실에서 합류 가 발생했을 시 재실자의 밀도와 속도 관계 및 유동계수를 분석하여 회귀식을 도출하였고, 피난시뮬레이션을 통해 재실자 수, 계단참, 계단폭이 변수로 작용하였을 때 계단실 내부의 재실자 행동특성 및 피난시간 등을 분석하여 계단 실에서의 피난안전성 향상을 위한 기초 데이터를 확보하였다.

\section{ABSTRACT}

In a fire incident case in a modern high-rise complex building, most occupants use the stairs to evacuate; hence, it is critical to secure the safety of vertical escape routes, such as the stairs. However, in Korea, the size of the stairwell is stipulated as a universal standard, and there are insufficient regulations and studies on the behavioral characteristics of occupants that may occur during the vertical evacuation of buildings. Therefore, in the evacuation experiment conducted at the W University in Japan, the relationship between the density and velocity of the occupants and the flow coefficient were analyzed during merging in the stairwell to derive a regression equation. When the stair width acted as a variable, the behavioral characteristics of the occupants and the evacuation time inside the stairwell were analyzed to obtain the basic data for improving the evacuation safety in the stairwell.

Keywords : Evacuation, Korean life safety code, Simulation, Stair evacuation, Evacuation experiments

\section{1. 서 론}

\section{1 연구 배경 및 목적}

최근의 건축물은 고층화, 대형화 되어가고 있다. 이러한 건축물은 다수의 재실자가 상주하고 있어, 화재 시 피난안
전에 대하여 다양한 문제가 발생할 것으로 판단된다. 이에 국내에서는 초고층 및 지하연계 방재 관련 특별법, 화재영 향제도평가, 성능위주설계 등을 통해 피난안전성을 확보하 기 위한 대책을 마련하고 있다. 하지만 피난안전성 평가를 위해 기초가 되는 재실자밀도, 보행속도, 피난경로의 확보,

${ }^{\dagger}$ Corresponding Author, TEL: +82-41-540-5497, FAX: +82-41-540-5738, E-Mail: jungangman@naver.com

(c) 2021 Korean Institute of Fire Science \& Engineering. All right reserved. 
피난자의 특성 등 재실자의 특성을 고려한 공학적 분석 및 데이터는 미비한 실정이다(1).

또한 대부분의 재실자는 외부로 피난하기 위해 각 층에서 계단을 이용하여 피난을 실시한다. 하지만 대다수의 재실자 가 계단실로 유입되면 체류가 발생하여 보행속도가 낮아지 고, 병목현상 등 다양한 문제가 발생할 것으로 사료됨에 따 라 관련 연구를 통한 대책마련이 필요한 실정이다. 이에 국 내에서는 용도별 출구유동계수 및 재실자 밀도조사리), 재난 약자의 보행속도 조사연구(4), 계단에서의 보행속도에 관한 연구(2,5) 등 지속적으로 관련 연구가 진행되었으나, 실험을 통 한 계단실에서의 피난 특성 분석에 관한 연구는 미비한 실정 이다. 피난안전성 향상을 위해서는 공학적 계산을 통한 피난 모델 구축 및 설계가 필요하며, 실제 실험데이터를 분석하여 행동특성을 파악하는 것도 중요한 요소일 것으로 사료된다.

따라서 본 연구에서는 계단실에서의 재실자의 피난행동 모델과 관련한 데이터를 구축하기 위해 일본의 $\mathrm{W}$ 대학에 서 수행된 실제 실험을 분석하였다. 실험은 계단에서 합류 가 발생할 때 군집밀도가 수직보행속도에 미치는 영향과 유동계수에 관한 것으로, 이에 대한 결과 데이터를 분석하 였다. 또한 피난시뮬레이션인 pathfinder를 이용해 재실자가 합류하여 발생하는 밀도와 속도관계에 대한 피난시간의 차 이를 분석하여, 계단실에서의 피난안전성 향상을 위한 데 이터를 확보하고자 하였다.

\section{2. 직통계단 피난 실험}

\section{1 실험의 필요성 및 목적}

건축물 화재 시 피난자의 보행속도는 열이나 연기의 발 생량 및 재실자의 특성이나 화재 시 발생되는 상황에 따라 다르게 나타난다. 기존에 수행된 연구에 따르면 수평한 복 도에서 일반 성인의 보행속도는 $1 \mathrm{~m} / \mathrm{s}$ 전후의 범위이지만, 재난약자의 경우 절반정도로 나타났다. 또한 계단에서의 피난은 기울기에 따라 다르지만 표준적인 단 높이에 따른 면의 경우 수평투영의 보행속도는 $0.5 \mathrm{~m} / \mathrm{s}$ 로 수평보행속도 의 절반정도이다 ${ }^{(2,5)}$.

$\mathrm{Seo}$ 등(2)은 실제 건축물에서 사용되고 있는 계단에서의 보 행속도를 측정하기 위하여 플랫폼에서 개찰구로 이동하는 계단에서 실험을 실시하였다. 그 결과 밀도가 1 persons $/ \mathrm{m}^{2}$ 일 때 $0.443 \mathrm{~m} / \mathrm{s}$ 의 보행속도가 나타났으며, 5 persons $/ \mathrm{m}^{2}$ 일 때 0.25 $\mathrm{m} / \mathrm{s}$ 로 감소하였다. Park ${ }^{(6)}$ 의 실험에 따르면 밀도가 1 persons $/ \mathrm{m}^{2}$ 일 때 $0.543 \mathrm{~m} / \mathrm{s}$ 의 보행속도가 나타났으며, 5 persons $/ \mathrm{m}^{2}$ 일 때 $0.16 \mathrm{~m} / \mathrm{s}$ 으로 감소하였다. 또한 小關은 하행계단에서 조사한 것으로서 1 persons $/ \mathrm{m}^{2}$ 에서 약 $0.65 \mathrm{~m} / \mathrm{s}$ 의 보행속도가 나타났으 며 5 persons $/ \mathrm{m}^{2}$ 일 때 약 $0.2 \mathrm{~m} / \mathrm{s}$ 로 감소하였다 ${ }^{(5)}$.

전술한 문헌들의 실험 조건 및 실험 당시의 상황은 모두 상이하지만 밀도에 따라 속도가 감소하는 것에서 공통적인 특징인 있는 것으로 확인되었다. 기존의 실험은 역사 등에 서 사용되는 직선형태의 계단에서 보행속도를 측정한 것으

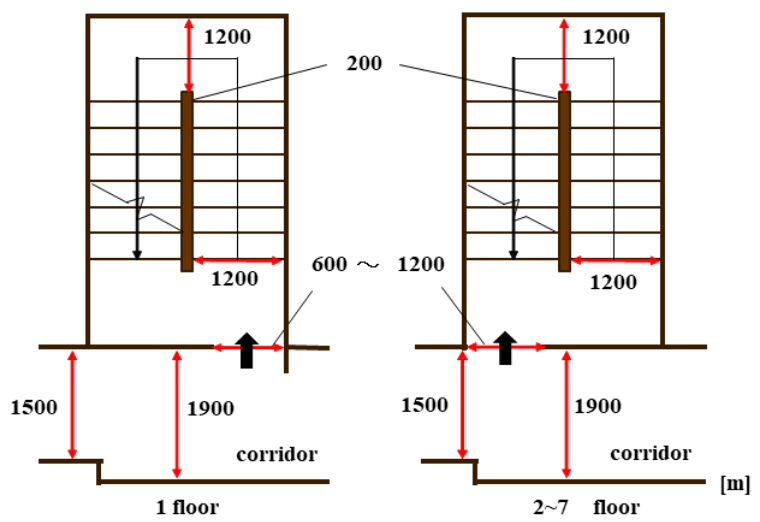

Figure 1. The dimensions of $\mathrm{W}$ univ. experiment.

로, 본 논문에서 분석하고자 하는 고층건축물의 직통계단 에서의 보행속도와는 차이가 있을 것으로 판단되어, 실험 의 분석을 실시하였다.

실험은 계단에서 각 보행자의 보행능력이 미치는 영향, 보행거리(실험자가 이동하는 층의 수)의 영향, 두 집단이 한 곳에서 합류되는 지점에서의 보행특성, 장애물에 따른 보행특성 변화 등을 파악하기 위해 수행되었다. 본 연구에 서는 각 보행자의 보행 특성을 식별하고 두 집단의 합류가 군중보행속도에 미치는 영향을 중점적으로 분석하여 이에 따른 문제점 및 행동특성을 도출한다.

\section{2 실험 개요}

실험은 2017년 11월 19일 일본 W 대학에서 진행되었으 며 일본 $\mathrm{T}$ 대학 $\mathrm{Lee}^{(7)}$ 의 논문을 참조하였다. 실험에는 거동 에 불편이 없는 20 세에서 40 세 사이의 남녀 181 명이 참여 하였으며 총 22 개의 실험이 44 회 진행되었다. 본 실험에서 사용된 계단의 치수를 나타낸 것은 Figure 1 과 같다.

본 논문에서는 진행된 많은 Case 중 군집 밀도와 군집 보 행속도의 관계와 군중의 합류에 따른 보행속도에 대한 변 화를 확인하기 위해 군중이 합류하는 Case 중 계단을 올라 가는 경우(이하 $\mathrm{DU})$ 와 계단을 내려가는 경우(이하 $\mathrm{DD})$ 를 분석하였고, 이 실험은 전체 중 각각 두 번씩 수행되었다.

먼저 계단을 올라가는 경우인 DU1은 67 명이 2층에서 6 층으로 올라가고, 3 층에서 68 명이 합류하는 것으로 설정되 었으며, DU2는 68 명이 2층에서 6층 까지 올라가고 67 명이 3 층에서 합류하는 것으로 설정되었다. 또한 계단을 내려가 는 경우인 $\mathrm{DD} 1$ 과 $\mathrm{DD} 2$ 는 68 명이 7 층에서 1 층으로 내려가 고, 67 명이 6층에서 합류하는 것으로 설정되었다. 실험에 대하여 나타낸 것은 Figure 2 와 같다.

실험의 관측은 계단참 및 해당 구역에 각각 카메라를 설 치하고, 피실험자 각각에게 식별 번호표를 부착하여 피난 행동패턴을 분석하였다.

\section{3 분석방법}

피난 시 밀도와 속도의 관계를 파악하고 피난 중 유량계 
Case DU

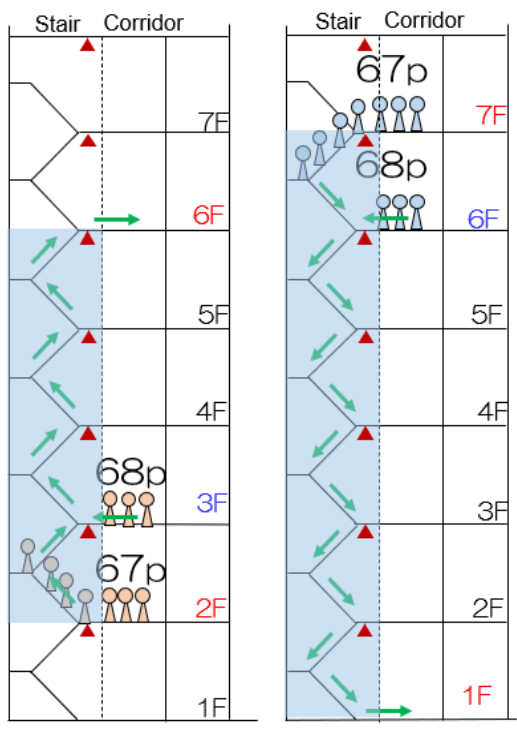

- : Video Camera
Figure 2. Experimental condition.

수의 변화를 확인하기 위하여 각 층의 비디오 카메라의 녹 화영상을 분석하여 데이터를 확보하였다.

또한 본 실험에서 나타난 피실험자의 군집밀도는 식(1) 을 사용하여 계산하였다.

$$
\rho=\frac{\text { persons }}{A}
$$

여기서, $\mathrm{A}$ 는 재실자가 점유하고 있는 면적, persons는 사 람의 수를 나타낸다.

계단과 계단이 이어지는 각 층의 계단참에서 밀도를 측 정하였다. 비디오를 분석하여 각 층의 계단참에서 피실험 자의 한발이 계단참에 닿아 들어오는 순간의 시간과 한발 이 계단에 닿아 나가는 순간의 시간을 확인하였다.

보행속도는 식(2)를 사용하였으며 거리는 두 가지 방법 으로 나누어 계산을 하였다. 또한 계단을 일반적으로 오르 거나 내려가는 사람 및 합류하는 사람의 차이, $\mathrm{DU}$ 와 $\mathrm{DD}$ 의 예상동선을 Figure 3에 나타내었다. (a)는 계단 폭인 $1.2 \mathrm{~m}$ 를 절반으로 나누어 안쪽으로 걷는 실험자를 내부 피실험 자, 바깥쪽으로 걷는 실험자를 외부 피실험자로 칭하고 원 의 둘레 공식을 사용하여 보행거리를 계산하였다. 내부 피 실험자의 반지름은 $0.4 \mathrm{~m}$, 외부 피실험자의 반지름을 $1 \mathrm{~m}$, 교차 피실험자의 반지름을 $0.7 \mathrm{~m}$ 로 측정하여 보행거리를 계산하였다. (b)는 외부에서 합류하여 올라가는 방향으로 이동하도록 설정하였으며 피타고라스 정리를 이용하여 보 행거리를 계산하였다. (c)는 외부에서 합류하며 내려가는 방향으로 가도록 설정한 것이며 합류 한 사람의 직선 보행 거리를 계산하였다. 교차하는 경우는 (b) 방법과 같이 피타 고라스의 정리를 이용하여 보행거리를 측정하였다.

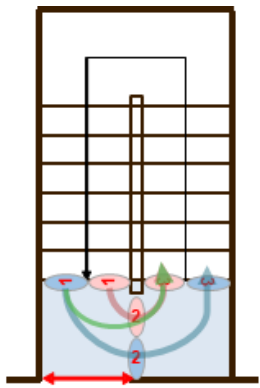

(a)

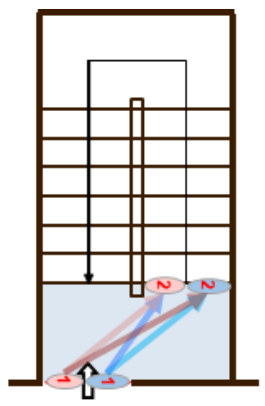

(b)

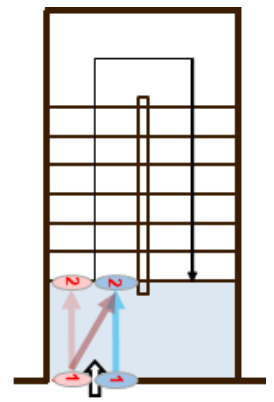

(c)
Figure 3. Distance formula, (a) Go up and down, (b) Joining case DU, (c) Joining case DD.

$$
v=\frac{l}{t_{2}-t_{1}}
$$

여기서, $\mathrm{t}_{2}$ 는 피실험자가 해당구역에서 유출된 시간, $\mathrm{t}_{1}$ 은 피실험자가 해당구역에 유입된 시간, $l$ 은 보행거리를 나타 낸다.

또한 유량계수는 식(3)을 사용하여 계산하였다.

$$
N=\frac{\sum \text { persons }}{B_{s t} \times t}
$$

먼저, $1 \mathrm{~s}$ 당 해당구역에서 유출되는 사람의 수를 합산했 으며 그 후의 값을 계단 폭 $1.2 \mathrm{~m}$ 로 나누어 계산하였다. 여기서, $B_{s t}$ 는 통로의 폭, $\mathrm{t}$ 는 시간을 나타낸다.

\section{4 분석결과}

본 실험을 분석한 결과는 아래와 같으며 본 연구에서는 밀도, 속도, 밀도와 속도의 관계, 유량계수에 관하여 분석 하였다.

\subsection{1 밀도}

DU case의 분석결과는 Figure 4와 같다. DU1과 DU2의 경우 합류되는 층인 3층에서 밀도가 3.85 persons $/ \mathrm{m}^{2}$ 로 가 장 높게 나타났으며 반면에 4 층과 5 층의 밀도는 가장 낮게 나타났다.

$\mathrm{DD}$ case의 분석결과는 Figure 5와 같다. DD2의 경우 합 류되는 층인 6층에서 밀도가 각각 3.85 persons $/ \mathrm{m}^{2}$ 과 3.53 persons $/ \mathrm{m}^{2}$ 으로 가장 높게 나타났으며 결합되지 않은 층의 밀도는 모두 유사하게 나타났다.

\subsection{2 속도}

DU case의 분석결과는 Figure 6과 같다. DU1과 DU2의 경우 합류되는 층인 3 층에서 속도가 각각 $0.36 \mathrm{~m} / \mathrm{s}$ 와 0.31 $\mathrm{m} / \mathrm{s}$ 로 가장 느리게 나타났으며 가장 속도가 빠른 4층과 5 층에 비하여 약 2 배 이상 차이가 나타났다. 


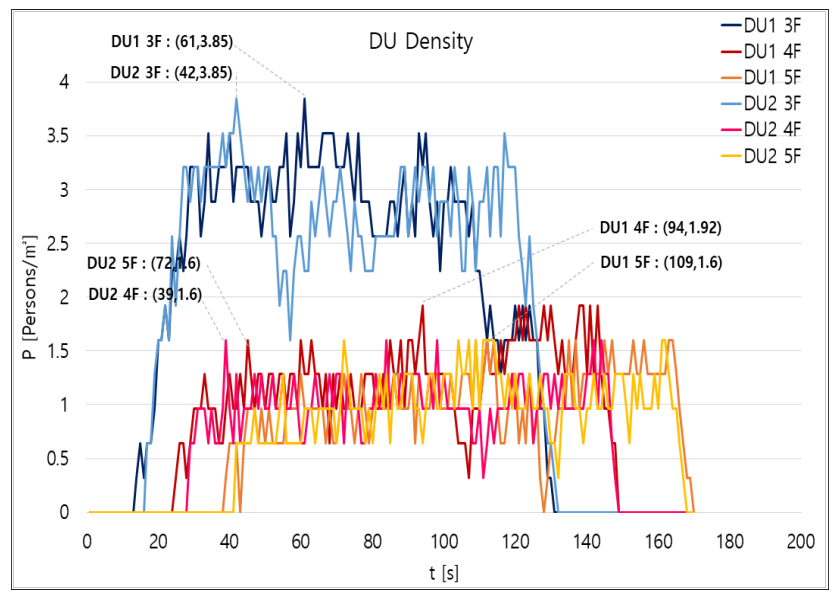

Figure 4. The density of the case DU.

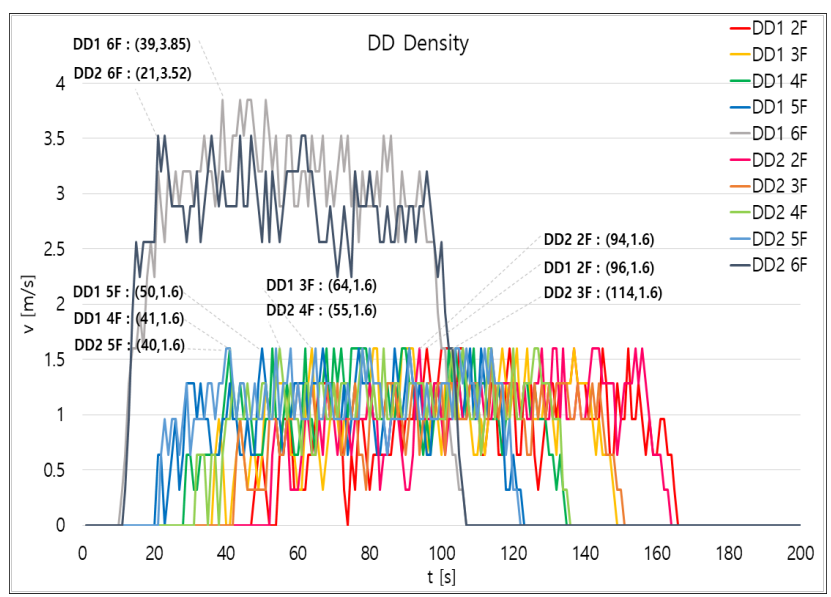

Figure 5. The density of the case DD.

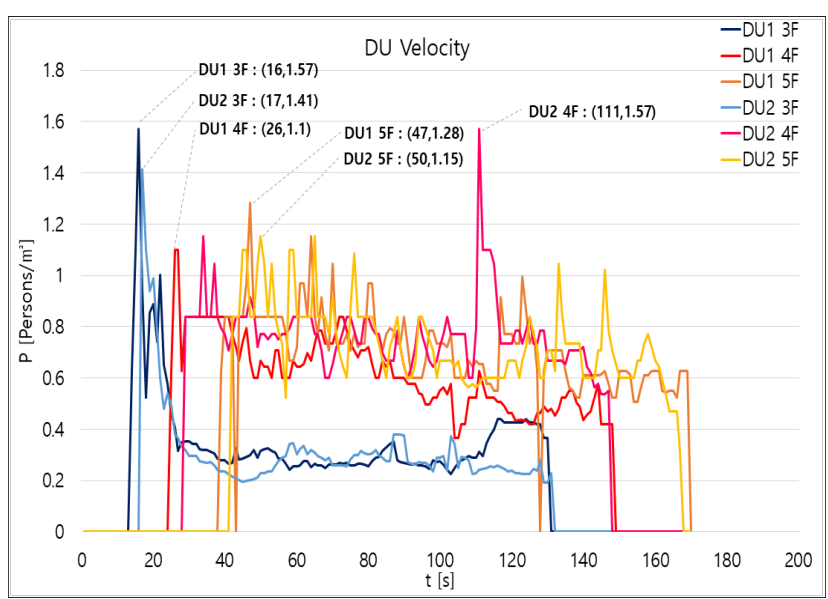

Figure 6. The velocity of the case DU.

$\mathrm{DD}$ case의 분석결과는 Figure 7과 같다. DD1과 DD2의 경우 합류되는 층인 6 층에서 속도가 각각 $0.31 \mathrm{~m} / \mathrm{s}$ 과 0.29 $\mathrm{m} / \mathrm{s}$ 로 가장 느리게 나타났으며 합류되지 않은 층에 비하여 약 두 배 이상의 차이가 나타났다.

합류되지 않은 층의 평균속도는 $\mathrm{DU}$ 의 경우 각각 0.66

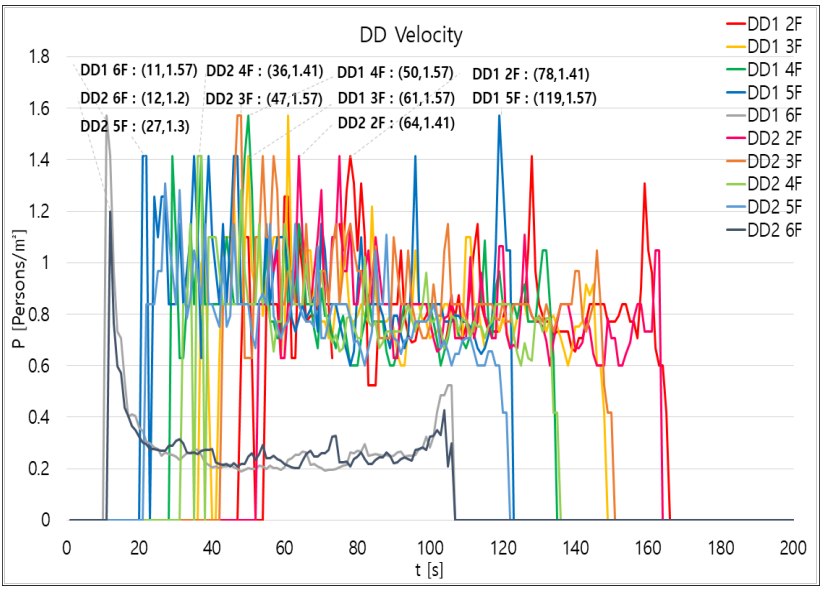

Figure 7. The velocity of the case DD.

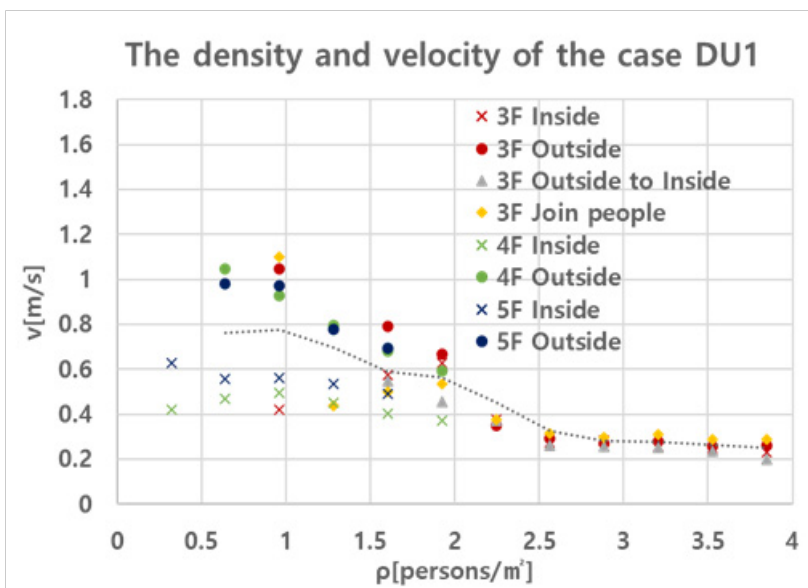

The density and velocity of the case DU2

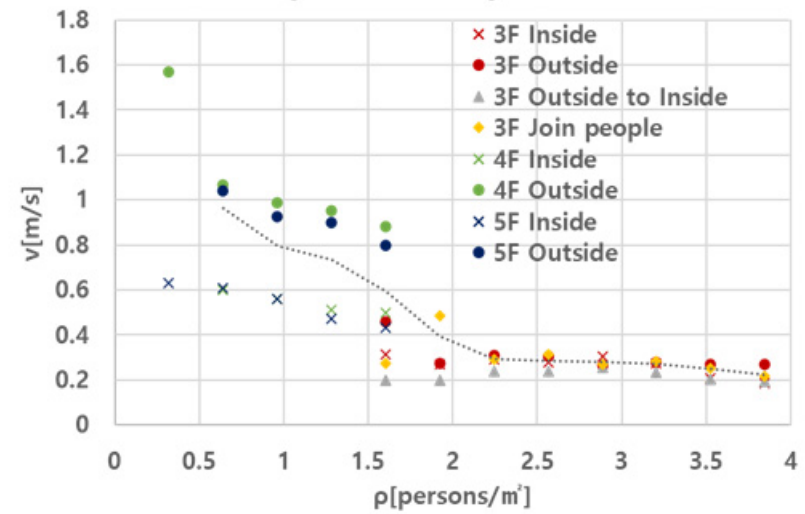

Figure 8. The density and velocity of the case DU.

$\mathrm{m} / \mathrm{s}$ 과 $0.75 \mathrm{~m} / \mathrm{s}$ 로 나타났다. $\mathrm{DD}$ 의 경우 각각 $0.85 \mathrm{~m} / \mathrm{s}$ 와 $0.83 \mathrm{~m} / \mathrm{s}$ 로 나타났으며 계단 하강 속도는 상승속도보다 평 균 $0.13 \mathrm{~m} / \mathrm{s}$ 정도 빠른 것으로 확인되었다.

\subsection{3 밀도와 속도의 관계}

$\mathrm{DU}$ 와 $\mathrm{DD}$ 의 밀도와 속도관계는 Figures 8, 9와 같으며, 반비례 관계로서 밀도가 증가하면 속도는 감소하였다. 또 


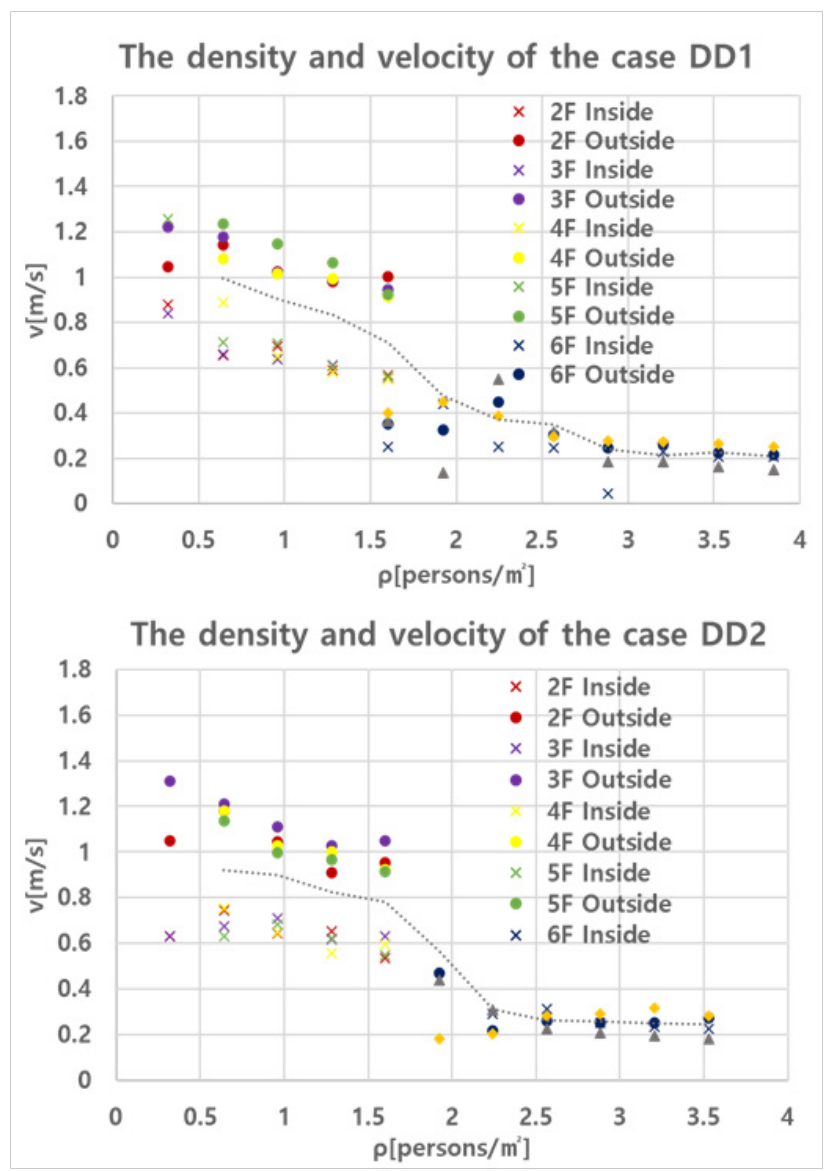

Figure 9. The density and velocity of the case DU.

한 외부에서 보행하는 피실험자가 내부에서 보행하는 피실 험자보다 빠른 속도로 보행하였다. 그래프의 형태에서 보 았을 때 내부그래프는 큰 변동이 없는 것과 반대로 외부그 래프는 크게 변동하였다. 이것은 피난 시 내부에서 보행하 는 사람은 앞사람의 유무에 관계없이 일정한 속도로 이동 한다는 것을 알 수 있다. 반면, 외부에서 보행한 피실험자 는 보행속도가 앞사람의 유무에 따라 크게 변동하였다. 이 것은 피난 시 내부에서 걷는 사람보다 외부에서 걷는 사람 이 앞사람의 유무에 따라 보행속도에 영향을 받는 다는것 을 나타낸다. 또한 밀도가 2 persons $/ \mathrm{m}^{2}$ 이상일 때 속도 변 화는 크게 변동하지 않았다.

\subsection{4 유량계수}

$\mathrm{DU} 1$ 의 경우 유량계수는 3 층에서 5 층으로 갈수록 각각 $0.98,0.92,0.88 \mathrm{persons} / \mathrm{m} / \mathrm{s}$ 로 나타났다. 또한 DU2의 경우 에도 유량계수는 3 층에서 5 층으로 갈수록 $0.98,0.95,0.92$ persons $/ \mathrm{m} / \mathrm{s}$ 로 나타나 상부로 올라갈수록 유량계수가 점차 감소하는 것으로 나타났다.

$\mathrm{DD} 1$ 의 경우 유량계수는 6 층에서 2층으로 내려갈수록 $1.2,1.14,1.11,1.06,1.02 \mathrm{persons} / \mathrm{m} / \mathrm{s}$ 로 나타났으며, DD2의 경우에도 6 층에서 2 층으로 내려 갈수록 $1.18,1.14,1.11$,

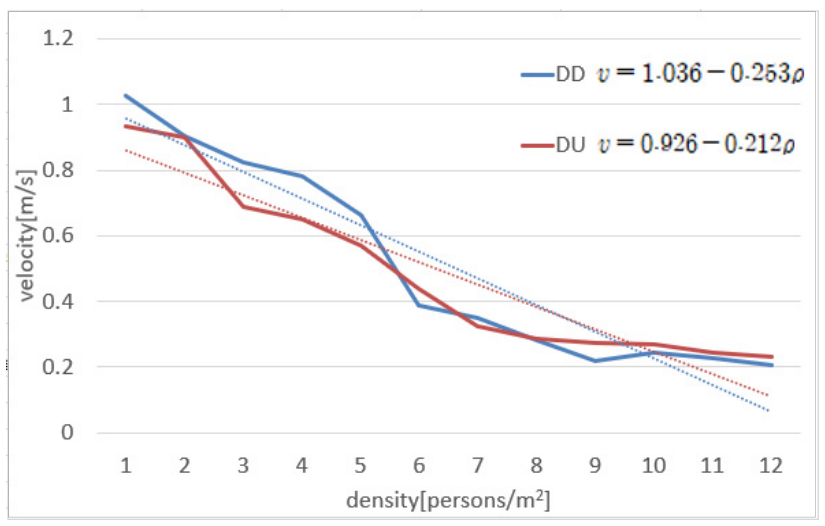

Figure 10. Simple regression analysis.

$1.08,1.05$ persons $/ \mathrm{m} / \mathrm{s}$ 로 나타나 하부로 내려갈수록 유량계 수가 점차 감소하는 것으로 나타났다.

이것은 합류된 지점에서는 일반적으로 이동하는 집단과 새로 유입되는 집단이 한 공간에 위치함으로서 높은 유량 계수가 나타나며 목표층으로 이동할수록 밀도가 감소되고 피난자의 질서가 유지됨에 따라 유량계수가 감소하는 것으 로 보인다.

\subsection{5 계단보행속도 회귀식 도출}

합류에 따라 각 층에서 유동하는 재실자의 보행속도를 분석하여 평균값을 도출하였다. 또한 독립변수인 밀도와 종속변수인 보행속도 사이의 선형관계를 파악하는 방식으 로 단순회귀분석을 통해 상향 및 하향 보행속도의 회귀식 을 도출해내었다. 그 결과 상행보행속도의 회귀식은 $v=0.926-0.212 \rho$, 하행보행속도의 회귀식은 $v=1.036-0.253 \rho$ 로 나타났다. 속도와 밀도의 관계그래프는 Figure 10에 나 타내었다.

\section{3. 피난시뮬레이션}

\section{1 피난시뮬레이션 구동조건 및 목적}

시뮬레이션 구동을 위한 조건은 Table 1에 나타내었다. 시뮬레이션 분석을 위해 2000명의 인원을 수용할 수 있는 임의의 건축물을 대상으로 실시하였다. 본 연구에서는 건 축물의 건축적 요소를 총 6 층, 연면적 약 $35,832 \mathrm{~m}^{2}$, 층고 $5 \mathrm{~m}$, 직통계단의 수 2 개, 피난구 1 개로 설정하였다. 또한 인체 표준은 어깨너비가 가장 넓은 20 대 남성을 기준으로 $40.20 \mathrm{~cm}$ 로 하였다 ${ }^{(8)}$.

또한 보행속도는 화재 시 재실자의 연령, 성별 등에 차 이를 보이기 때문에 한국건설기술연구원에서 조사한 어린 이, 청소년, 성인, 노인의 보행속도의 평균치인 $1 \mathrm{~m} / \mathrm{s}$ 를 사 용하였다 ${ }^{(9)}$.

시뮬레이션의 변수는 Table 2에 나타내었다. 비교를 위 해 국내의 건축법과 미국의 NFPA101에서 제시하고 있는 계단폭, 계단참크기를 기준으로 하였다. 국내에서는 소방 
Table 1. Simulation Conditions

\begin{tabular}{l|l|c|c}
\hline & \\
\hline
\end{tabular}

Table 2. Stair width and Stairwell Size Regulations in Korea and the United States

\begin{tabular}{c|c|c|c|c}
\hline Division & \multicolumn{2}{|c|}{ Building code } & \multicolumn{2}{|c}{ NFPA101 ${ }^{(10)}$} \\
\hline \hline $\begin{array}{c}\text { Capacity } \\
\text { [persons] }\end{array}$ & - & - & $<2000$ & $\geq 2000$ \\
\hline $\begin{array}{c}\text { Stair width } \\
{[\mathrm{mm}]}\end{array}$ & - & 900 & 1120 & 1420 \\
\hline $\begin{array}{c}\text { Stairwell } \\
\text { size }[\mathrm{mm}]\end{array}$ & $\begin{array}{c}1200 \mathrm{~mm} \text { when } \\
\text { the step height } \\
\text { exceeds } 3 \mathrm{~m}\end{array}$ & $\begin{array}{c}1525 \mathrm{~mm} \text { or more in } \\
\text { the evacuation } \\
\text { direction }\end{array}$ \\
\hline
\end{tabular}

시설의 성능위주 설계 방법 및 기준 별표1에서 수용인원을 건축물 용도에 따라 구분하고 있으나, 계단 폭 및 계단참에 는 적용하지 않기 때문에 본 연구에서는 고려하지 않는다.

본 연구에서는 계단실에 일반적으로 피난하는 집단과 각 층에서 유입하는 집단이 계단실에서 합류됨에 따라 피 난 시 발생할 우려가 있는 밀도증가에 따른 보행속도 저하 현상을 분석하고 그에 따른 해결방안을 제시한다.

\section{2 피난시뮬레이션 개요}

본 연구에서는 계단실에서 나타나는 재실자의 피난행동 특성을 파악하기 위해 미국의 Thunderhead Engineering에서
개발한 Pathfinder simulator를 사용하였다. 이 시뮬레이션 Tool은 가장 근접한 출구를 경유하여 가장 가까운 출입구 를 재실자가 이용하도록 기본 알고리즘이 구성되어 있으 며, 장애물을 선회하여 피난할 수 있다. 또한 특수한 장소 등 다양한 공간 구현이 가능하며, 피난 시 가장 문제되는 요인 중 하나인 병목현상 등도 확인이 가능함에 따라 본 시뮬레이션을 구동하여 분석을 실시하였다.

\section{3 피난시뮬레이션 결과}

건축물에서의 피난 시 재실자의 합류에 따른 피난성상 을 파악하고, 재실자의 밀도 감소를 위한 대책을 마련하기 위하여 재실자 수, 계단참 폭, 계단폭을 변수로 두고 총 12 가지 시나리오를 통해 시뮬레이션을 구동하였다. 시뮬레이 션의 사용된 변수와 이에 대한 결과는 Table 3 과 같다.

재실자 수가 1000 명일 경우 계단참의 크기가 $1200 \mathrm{~mm}$ 일 때 계단폭이 900, 1120, $1420 \mathrm{~mm}$ 로 증가함에 따라 피난 완료시간은 $1071,872,662 \mathrm{~s}$ 로 감소하였다. 또한 동일한 재 실자 수로 설정하고 계단참의 크기가 $1525 \mathrm{~mm}$ 일 때 계단 폭이 증가함에 따라 피난완료시간은 $1060,871,661 \mathrm{~s}$ 로 감 소하였다. 이것은 계단폭이 증가함에 따라 피난완료시간이 감소하는 것을 나타낸다. 또한 해당 연면적의 건축물에 재 실자가 1000 명일 때 계단참의 크기에 따라서는 피난시간이 크게 달라지지 않는 것을 알 수 있다.

재실자 수가 2000 명일 경우 계단참의 크기가 $1200 \mathrm{~mm}$ 일 때 계단폭이 900, 1200, $1420 \mathrm{~mm}$ 로 증가함에 따라 피난완 료시간은 $1866,1503,1137 \mathrm{~s}$ 로 감소하였다. 또한 동일한 재 실자 수로 설정하고 계단참의 크기가 $1525 \mathrm{~mm}$ 일 때 계단 폭이 증가함에 따라 피난완료시간은 2014, 1607, 1209 s로 나타났다. 계단폭이 증가함에 따라 피난속도는 감소하였다. 또한 해당 연면적의 건축물에서는 재실자 수가 2000명일 때 계단참의 크기가 증가할수록 피난시간이 증가하였다.

이것은 계단실이 2 개소인 건축물에서 내부 재실자의 수 가 2000 명 이상일 때 계단참의 크기를 $1200 \mathrm{~mm}$ 이상으로 설정하면 계단참에서의 밀도증가로 인해 피난시간에 영향 을 주는 것으로 보인다.

또한 각 층에서 계단실로 일제히 피난을 시작했을 때 밀 도 증가로 인한 체류가 발생하여 상부 층으로 갈수록 체류 지속시간이 증가하였다.

\section{4. 결 론}

건축물의 수직피난 시 각층 계단실에서의 밀도와 속도 변화를 분석하기 위해 본 실험에서 나타난 결과를 토대로 회귀식을 도출했다. 또한 피난시뮬레이션을 통하여 합류에 따른 밀도-속도 관계를 분석하였으며 수용인원과 계단실 내부의 건축적 요소의 변화에 따른 피난시간의 차이를 분 석하였다.

a) 계단실에서 합류가 발생함에 따라 합류지점의 밀도는 
Table 3. Evacuation Simulation Results

\begin{tabular}{|c|c|c|c|c|c|c|c|c|c|c|c|c|c|}
\hline \multirow{2}{*}{$\begin{array}{c}\text { All } \\
\text { personnel }\end{array}$} & \multirow{2}{*}{$\begin{array}{l}\text { Stairwell size } \\
{[\mathrm{mm}]}\end{array}$} & \multirow{2}{*}{$\begin{array}{l}\text { Stair width } \\
{[\mathrm{mm}]}\end{array}$} & \multirow{2}{*}{$\begin{array}{c}\text { Evacuation } \\
\text { completion time [s] }\end{array}$} & \multicolumn{5}{|c|}{ Maximum duration of stay [s] } & \multicolumn{5}{|c|}{$\begin{array}{l}\text { Maximum number of people } \\
\text { staying [persons] }\end{array}$} \\
\hline & & & & $6 \mathrm{~F}$ & $5 \mathrm{~F}$ & $4 \mathrm{~F}$ & $3 \mathrm{~F}$ & $2 \mathrm{~F}$ & $6 \mathrm{~F}$ & $5 \mathrm{~F}$ & $4 \mathrm{~F}$ & $3 \mathrm{~F}$ & $2 \mathrm{~F}$ \\
\hline \multirow{3}{*}{1000} & \multirow{3}{*}{1200} & 900 & 1071 & 532 & 411 & 227 & 117 & - & 15 & 15 & 15 & 15 & 5 \\
\hline & & 1120 & 872 & 400 & 344 & 169 & 87 & - & 16 & 16 & 16 & 15 & 8 \\
\hline & & 1420 & 662 & 283 & 192 & 91 & 37 & - & 16 & 16 & 16 & 15 & 6 \\
\hline \multirow{3}{*}{1000} & \multirow{3}{*}{1525} & 900 & 1060 & 516 & 423 & 250 & 90 & - & 19 & 19 & 19 & 18 & 5 \\
\hline & & 1120 & 871 & 384 & 281 & 187 & 74 & - & 20 & 20 & 20 & 18 & 5 \\
\hline & & 1420 & 661 & 288 & 210 & 124 & 47 & - & 20 & 20 & 20 & 18 & 5 \\
\hline \multirow{3}{*}{2000} & \multirow{3}{*}{1200} & 900 & 1866 & 1158 & 916 & 604 & 298 & - & 25 & 21 & 19 & 16 & 5 \\
\hline & & 1120 & 1503 & 940 & 691 & 458 & 220 & - & 16 & 16 & 16 & 17 & 5 \\
\hline & & 1420 & 1137 & 664 & 498 & 328 & 156 & - & 17 & 16 & 17 & 16 & 6 \\
\hline \multirow{3}{*}{2000} & \multirow{3}{*}{1525} & 900 & 2014 & 1264 & 978 & 586 & 285 & - & 28 & 20 & 20 & 18 & 5 \\
\hline & & 1120 & 1607 & 1031 & 800 & 478 & 219 & - & 20 & 21 & 20 & 19 & 6 \\
\hline & & 1420 & 1209 & 752 & 547 & 323 & 145 & - & 18 & 21 & 20 & 20 & 5 \\
\hline \multirow{2}{*}{\multicolumn{2}{|c|}{ Velocity changes with density }} & \multicolumn{2}{|c|}{ Density [persons $/ \mathrm{m}^{2}$ ] } & \multicolumn{2}{|c|}{3} & \multicolumn{2}{|c|}{2} & \multicolumn{3}{|c|}{1} & \multicolumn{3}{|c|}{0} \\
\hline & & \multicolumn{2}{|c|}{ Velocity $[\mathrm{m} / \mathrm{s}]$} & \multicolumn{2}{|c|}{0.3} & \multicolumn{2}{|c|}{0.42} & \multicolumn{3}{|c|}{0.6} & \multicolumn{3}{|c|}{1} \\
\hline
\end{tabular}

약 3.85 persons $/ \mathrm{m}^{2}$ 로 나타났다. 또한 밀도가 증가함에 따라 보행속도는 감소하였으며, 유동계수는 합류지점에서 가장 크게 나타났으며, 목표층으로 도달 할수록 내부 재실자의 밀 집이 해소되고 질서가 유지됨에 따라 점차 감소하였다. 또한 계단실에서의 보행속도는 상행일 경우 밀도가 1 persons $/ \mathrm{m}^{2}$ 일 경우 $0.714 \mathrm{~m} / \mathrm{s}$ 로 나타났으며 3 persons $/ \mathrm{m}^{2}$ 일 경우 0.29 $\mathrm{m} / \mathrm{s}$ 로 나타났다. 또한 하행일 경우 밀도가 1 persons $/ \mathrm{m}^{2}$ 일 경우 $0.783 \mathrm{~m} / \mathrm{s}$ 로 나타났으며 3 persons $/ \mathrm{m}^{2}$ 일 경우 $0.277 \mathrm{~m} / \mathrm{s}$ 로 나타났다. 이에 따라 직통계단에서 밀도에 따른 보행속도 에 관한 회귀식은 다음과 같이 도출되었다.

상행: $v=0.926-0.212 \rho$

하행: $v=1.036-0.253 \rho$

본 실험에서는 직통계단의 보행속도를 측정하여 약간의 수평보행속도가 개입된 것으로 보인다. 따라서 건축물의 피난모델 및 성능설계 시 계단의 형태에 따라 피난속도에 차이를 두어 보다 정확한 계산을 하는 것이 바람직할 것으 로 생각된다.

b) 피난시뮬레이션을 통해 밀도와 속도의 관계를 분석한 결과 보행속도를 $1 \mathrm{~m} / \mathrm{s}$ 로 설정하였을 때 밀도가 3 persons $/ \mathrm{m}^{2}$ 일 경우 $0.3 \mathrm{~m} / \mathrm{s}$ 로 나타났으며, 1 persons $/ \mathrm{m}^{2}$ 일 경우 $0.6 \mathrm{~m} / \mathrm{s}$ 로 나타났다. 또한 각층에서 인원이 유입됨에 따라 최상층 인 6층에서는 최대체류시간이 가장 높게 나타났다.

또한 건축물 내 수용인원이 1000 명일 경우 계단참의 크 기에 따라 피난완료시간은 크게 변화하지 않았다. 반면에 수용인원이 2000명일 때 계단참의 크기가 늘어남에 따라 피난완료시간이 증가하였다. 수용인원이 증가할 경우 계단
실의 계단참의 면적이 넓으면 피난면적이 증가하여 피난이 원활이 이루어 질 것으로 예상되었던 것과는 달리 계단참 의 크기가 증가할수록 계단실 내부의 밀도가 증가하여 피 난시간이 증가하였다. 이것은 재실자밀도가 높은 용도의 건축물일수록 계단참의 크기를 확장하는 것은 피난을 하는 데 있어 불리한 조건이 조성될 수 있을 것으로 판단된다.

따라서 수직피난에서의 피난모델 및 성능설계 시 공학 적인 계산을 통해 수용인원에 따라 계단실의 구조 등에 차 이를 두어야 할 것으로 보인다.

\section{후 기}

본 연구는 소방청 재난현장긴급대응기술개발사업(20015074) 의 연구비 지원으로 수행되었습니다.

\section{References}

1. D. G. Seo, E. K. Hwang and Y. J. Kwon, "A Study on the Investigation of Outflow Coefficient in Exit and Proposal of Investigation Method for Egress Safety Plan of PBD", Architectural Institute of Korea, Vol. 26, No. 1, pp. 167174 (2010).

2. D. G. Seo, E. K. Hwang and Y. J. Kwon, "An Investigation Study on the Walking Speed of Crowd for Egress Safety of PBD”, Architectural Institute of Korea, Vol. 26, No. 12, pp. 99-106 (2010).

3. D. G. Seo, Y. C. Shin, J. Y. Lee and Y. J. Kwon, "An Investigation Study on the Coefficient of Occupants Density 
for Performance Evacuation Capacity Computation in Buildings", Fire Science and Engineering, Vol. 23, No. 5, pp. 1-8 (2009).

4. H. R. Hong, D. G. Seo, Y. J. Hasemi and Y. J. Kwon, "A study on the Walking Speed of Crowd for Safety Evacuation Design of the Elderly", Fire Science and Engineering, Vol. 25, No. 1, pp. 19-26 (2011).

5. Ministry of Construction of Japan Notice, "Resolution and Calculation of Evacuation Safety Certificate Act", Japan, p. 42 (2001).

6. J. S. Park, "A Study on the Model for Prediction of Egress Behavior Considering Egress Behavior during Building Fires", Doctoral thesis, University of Seoul, p. 128 (2004).
7. Y. L. Lee, "Experimental Study on the Evacuation Procedures via Staircase $\sim$ Flow coefficient and Relationship between Density and Velocity ", Master's thesis, Tokyo University of Science (2020).

8. Size Korea, "Survey of Korean Human Body Dimensions" (2015).

9. Y. H. Yu, H. J. Shin. E. K. Hwang, C. S. An., O. S. Kwon, H. J. Yun and Y. S. Lim, "Development of Fire Spread Prevention and Escape Safety Design Technique According to Standard Fire Model", KICT 2009-129, Korea Institute of Construction Technology (2009).

10. NFPA, "NFPA101, Life Safty Code", National Fire Protection Association, p. 165 (2015). 